exemplo. Nós fomos caminhando, com pesquisas em comunidades pobres, em periferias, sempre voltados à realidade social da maioria da população brasileira.

Quanto às perspectivas da Psicologia Social, atualmente nós estamos com o campo em aberto. Há muita pesquisa a ser feita e o grande desafio agora é chegarmos às categorias do pacto social; porque toda psicologia é social, a não ser que você assuma que o homem possa năo ser histórico.
Nesse sentido, acho que as perspectivas sāo grandes. Demos um salto qualitativo, estamos sentindo que há um movimento que é brasileiro. A ABRAPSO - Associação Brasileira de Psicologia Social -, que se reúne na SBPC, em âmbito nacional e em assembléias regionais, durante o ano, é um exemplo disso. Dá para perceber que o movimento está avançando, não só com psicólogos mas também com assistentes sociais, antropólogos, sociólogos, que precisam da visão da Psicologia.

\title{
Ideologia: o ponto fundamental da
}

\section{discussão}

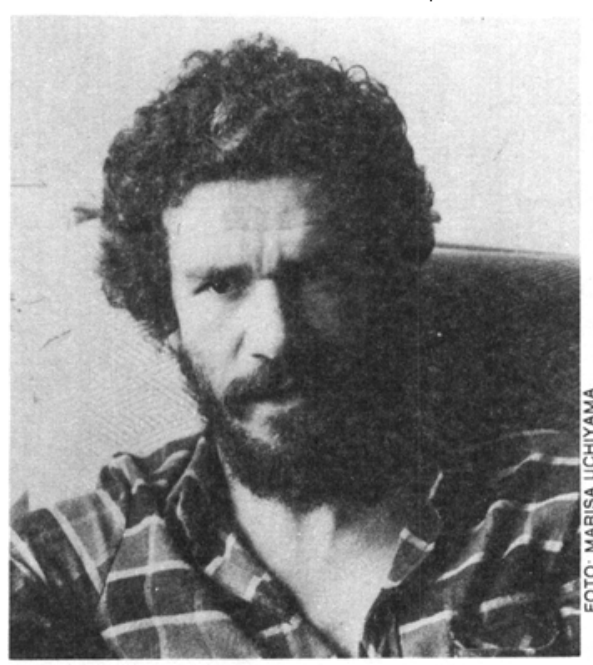

Wanderley Codo:

Wanderlei Codo: A proposta da Tecnologia Social se apresenta como uma nova abordagem em Psicologia Social, capaz de resolver problemas que vão desde a "persuasảo da esposa quanto à melhor localização de um móvel na sala até a resoluçăo de crises internacionais". Mas o que há de novo na Tecnologia Social? Segundo o próprio Varela, a novidade é exatamente esta: o uso da Psicologia para resolver problemas sociais, formando um aparato tecnológico. Evidentemente, qualquer ciência - e principalmente a nossa, voltada à compreensão do comportamento humano - tem como razẫo a intervenção social.
Tomemos Freud como parâmetro: sua preocupação era resolver conflitos de seus pacientes e por isso, exatamente, fundamentou e desenvolveu toda uma teoria que ainda hoje influencia a nossa compreensāo do Homem. A diferença nas duas abordagens é a consciência da complexidade dos problemas humanos, que Freud sempre explicitou e Varela parece ignorar. $O$ trabalho de Varela constitui uma autêntica "receita" para resolver problemas sociais: Nesse sentido se assemelharia muito aos livros que entulham as livrarias do tipo "como fazer amigos e influenciar pessoas", não fosse um certo colorido cientificista emprestado pela citação de alguns nomes respeitados na área.

Vejamos um exemplo de intervenção do tecnólogo: um dos problemas que resolveu foi o seguinte: uma empresa decidiu trocar o gerente e o escolhido para o posto foi uma pessoa de outra filial, provocando uma reaçāo de mal-estar nos funcionários preteridos para o cargo.

$O$ cientista foi chamado, então, a intervir exatamente para que a decisăo se concretizasse "sem traumas para a empresa". Qualquer pessoa de bom senso saberia que as causas desse problema estão sediadas na estrutura alienada de trabalho na sociedade contemporânea - que permite aos diretores alterar a seu bel prazer os quadros de profissionais da empresa sem que os próprios tenham direito a opinar sobre isso - e nas características do mercado capitalista, em que a competição frenética angustia qualquer trabalhador numa perspectiva de mudança. $O$ que fez o senhor Varela?

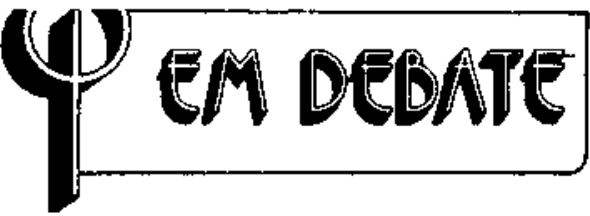

Tratou de persuadir os trabalhadores, candidatos naturais para o cargo, de que nāo eram as pessoas mais aptas para aquele posto.

Estamos diante de um duplo engodo: nem a realidade social cabe no receituário do tecnólogo e muito menos as soluções encontradas são capazes de resolver qualquer coisa, exceto o problema imediato do dirigente em. presarial. Estamos diante de uma Tecnologia Social sem dúvida voltada a encobrir os problemas sociais e a serviço dos meios de produção.

\section{"O MUNDO ESTÁ CARENTE DE UMA TECNOLOGIA SOCIAL"}

Quando se pergunta qual o papel da Psicologia Social nesse contexto, eu diria que o que pode nos interessar é o seguinte: porque o mero exercício do charlatanismo merece atenção de alguns pesquisadores considerados sérios nessa área de conhecimento?

Estamos vivendo numa sociedade psicologizada. Nunca os psicólogos tiveram tanto espaço nos meios de comunicaçăo de massa como hoje. Alguns de nossos livros ganham status de best-seller, como ocorreu com Skinner, revistas especializadas são encontradas em qualquer banca de jornal, nosso vocabulário técnico está popularizado, etc.. E, infelizmente, não é por uma demonstração cabal de competência dos psicologos que essa situação se apresenta. $E$ antes, por atravessarmos a mais grave crise que o capitalismo já enfrentou, por estarmos diante de um quandro social carente de mudanças e com uma população desorganizada politicamente para enfrentar essa necessidade. Ou seja, uma situação propicia para o aparecimento do charlatanismo. De um lado, uma espectativa cada vez maior de soluções para a crise social e, de outro, a falta de instrumentos concretos para realizá-las.

Eis algo em que concordo titeralmente com Jacobo Varela: o mundo está carente de uma Tecnologia Social. Mas que seja capaz de resolver não apenas querelas administrativas das empresas mas, principalmente, capaz de instrumentalizar o cidadāo para a busc. de sua própria cidadania. 